\title{
PERAN ORANGTUA DALAM PEMBELAJARAN DARING DIMASA PANDEMI COVID-19
}

\section{THE ROLE OF PARENTS IN ONLINE LEARNING DURING THE COVID-19 PANDEMIC}

\author{
Siti Lestari ${ }^{1^{*}}$, Minsih Zifa ${ }^{2}$ \\ ${ }^{* 1}$ PPG Prajabatan PGSD, Universitas Muhammadiyah Surakarta, Indonesia \\ ${ }^{2} P G S D$, Universitas Muhammadiyah Surakarta, Indonesia \\ *1 slestari.sl406@gmail.com \\ 2min139@ums.ac.id
}

\begin{tabular}{l}
\hline \multicolumn{1}{c}{ Article Info } \\
Historical Articles \\
Submitted: 2021-05-15 \\
Revised: 2021-06-17 \\
Issued: 2021-06-30
\end{tabular}

Keywords: The Role of Parents, Online Learning,

The Covid-19 Pandemic

Abstract

This study is a qualitative descriptive study that aims to determine the role of parents in online learning during the covid-19 pandemic. This study took a sample of 27 people as guardians of grade $3 \mathrm{~A}$ students at SD Negeri 1 Panunggalan. This research method uses a qualitative approach with a descriptive method. Data was obtained using a liters scale instrument in the form of a questionnaire consisting of 28 questions and containing 14 negative questions and 14 positive questions. The results of this study were parents who strongly agreed that learning at home could help children learn during the covid 19 pandemic as many as 5 respondents or $18.52 \%$, parents motivated children during learning at bome as many as 5 respondents or $18.52 \%$, parents find it easier to do bomework if children study at school as many as 9 respondents or 33.33\%, and parents feel happy for teachers who always give assignments to children as many as 10 respondents or $37.04 \%$. As for negative statements, parents tend to disagree with learning done at home. The results of the negative statements are that learning at school is less able to improve the quality of children's learning as many as 23 respondents or $85.18 \%$, parents never provide motivation while children study at home as many as 22 respondents or $81.48 \%$, and parents never help children learn as much 21 respondents or $77.78 \%$. It can be concluded that learning at home is not much better than learning at school.

\section{Abstrak}

Kata kunci: Peran Penelitian ini merupakan penelitian deskriptif kualitatif yang bertujuan untuk Orangtua, Pembelajaran Daring, Masa Pandemi Covid19 mengetahui peran orangtua dalam pembelajaran daring dimasa pandemi covid-19. Penelitian ini mengambil sampel 27 orang sebagai wali murid kelas 3A SD Negeri 1 Panunggalan. Metode penelitian ini menggunakan pendekatan kualitatif dengan metode deskriptif. Data diperoleh dengan menggunakan instrument skala liters berupa angket yang terdiri dari 28 pertanyaan dan berisikan 14 pertanyaan yang negatif dan 14 pertanyaan yang positif. Hasil dari penelitian ini orangtua yang merasa sangat setuju pembelajaran di rumah dapat membantu anak dalam belajar selama pandemic covid 19 sebanyak 5 responden atau 18,52\%, orangtua memberikan motivasi kepada anak selama pembelajaran berlangsung di rumah sebanyak 5 responden atau $18,52 \%$, orangtua merasa lebih mudah mengerjakan pekerjaan rumah jika anak belajar di sekolah sebanyak 9 responden atau 33,33\%, dan orangtua merasa senang kepada guru yang selalu memberikan tugas kepada anak sebanyak 10 responden atau 37,04\%. Sedangkan untuk pernyataan yang negative, orangtua cenderung tidak setuju terhadap pembelajaran yang dilakukan dirumah. Hasil dari pernyataan negative yaitu pembelajaran di sekolah kurang dapat meningkatkan kualitas pembelajaran anak sebanyak 23 responden atau 85,18\%, orangtua tidak pernah memberikan motivasi selama anak belajar di rumah sebanyak 22 responden atau $81,48 \%$, dan orangtua tidak pernah membantu anak belajar sebanyak 21 responden atau $77,78 \%$. Dapat disimpulkan bahwa pembelajaran di rumah tidak jauh lebih baik daripada pembelajaran di sekolah. 


\section{PENDAHULUAN}

Orangtua yaitu terdiri dari ayah dan ibu. Orangtua memiliki peran penting dalam membimbing dan mendampingi anak-anaknya baik dalam pendidikan formal maupun nonformal. Peran orangtua itu sendiri dapat mempengaruhi perkembangan anak dalam aspek kognitif, afektif, dan psikomotor. Menurut (Surur, 2018) "Peran yaitu perangkat tingkah yang diarapkan dimiliki oleh orang yang berkeduduan dalam masyarakat. Sedangkan menurut (Risthantri \& Sudrajat, 2015) menyatakan bawa "Peran adalah pola tingkah laku tertentu yang merupakan ciri-ciri khas semua petugas dari pekerjaan atau jabatan tertentu”. Menurut (Lailiyah \& Ridlwan, 2020) "Peran orangtua merupakan cara yang digunakan oleh orangtua berkaitan dengan pandangan mengenai tugas yang harus dijalankan dalam mengasuh anak". (Siregar, 2018) menyatakan bahwa "orang tua memiliki kewajiban dan tanggung jawab untuk mengasuh, memelihara, mendidik, dan melindungi anak".

Berdasarkan pengertian tersebut dapat disimpulkan bahwa peran orang tua yaitu cara yang digunakan oleh orang tua atau keluarga dalam menjalankan tugas dalam mengasuh, mendidik, melindungi, dan mempersiapkan anak dalam kehidupan bermasyarakat. Peran orang tua dalam pendidikan merupakan sesuatu yang sangat penting untuk menentukan keberhasilan pendidikan anak-anaknya. Pendidik pertama dan utama adalah orangtua. menyatakan bahwa (Fhatri, 2020) "peran orang tua dalam pendidikan adalah sebagai pendidik, pendorong, fasilitator dan pembimbing".

Pembelajaran daring merupakan pembelajaran yang menggunakan jaringan internet dengan aksesibilitas, konektivitas, fleksibilitas, dan kemampuan untuk memunculkan berbagai jenis interaksi pembelajaran. Seperti yang disampaikan oleh (Jannet, 2015) menunjukkan bahwa penggunaan internet dan teknologi multimedia mampu merombak cara penyampaian pengetahuan dan dapat menjadi alternatif pembelajaran yang dilaksanakan dalam kelas tradisional. Pembelajaran daring adalah pembelajaran yang mampu mempertemukan guru dan siswa untuk melaksanakan interaksi pembelajaran dengan bantuan internet ( F. Handayani, 2020b). Pada tataran pelaksanaanya pembelajaran daring memerlukan dukungan perangkatperangkat mobile seperti smarphone atau telepon adroid, laptop, komputer, tablet, dan iphone yang dapat dipergunakan untuk mengakses informasi kapan saja dan dimana saja (Rifqi, 2016). Sekolah Dasar pada masa WFH perlu melaksanakan penguatan pembelajaran secara daring (Suspahariati \& Susilawati, 2020). Pembelajaran secara daring telah menjadi tuntutan dunia pendidikan sejak beberapa tahun terakhir (F. Handayani, 2020b). Pembelajaran daring dibutuhkan dalam pembelajaran di era revolusi industri 4.0 (Prasetyo \& Sutopo, 2018).

Mengingat pentingnya peran orangtua dalam pembelajaran selama pembelajaran daring, tentunya sangat penting jika orangtua dapat mendampingi dan memotivasi anak selama pembelajaran. Karena anak belum dapat belajar dengan mandiri, terlebih lagi anak belum memiliki gadget sendiri. Banyak anak yang tidak dapat mengerjakan tugas dikarenakan kesibukan orangtua yang bekerja.

Dari permasalahan di atas dibutuhkan peran orangtua dalam pembelajaran agar dapat membimbing anak dalam belajar, motivasi, dorongan belajar. Dengan Penggunaan teknologi mobile mempunyai sumbangan besar dalam lembaga pendidikan, termasuk di dalamnya adalah pencapaian tujuan pembelajaran jarak jauh (Divayana, 2017). Berbagai media juga dapat digunakan untuk mendukung pelaksanaan pembelajaran secara daring. Misalnya kelas-kelas virtual menggunakan layanan Google Classroom, Edmodo, dan Schoology (Lyimo et al., 2017), dan applikasi pesan instan seperti WhatsApp (Arrosyad et al., 2021). Pembelajaran secara daring bahkan dapat dilakukan melalui media social seperti Facebook dan Instagram (Prastyo \& Nuswantari, 2020). Pembelajaran daring menghubungkan siswa dengan sumber belajarnya (database, pakar/instruktur, perpustakaan) yang secara fisik terpisah atau bahkan berjauhan 
namun dapat saling berkomunikasi, berinteraksi atau berkolaborasi (secara langsung/synchronous dan secara tidak langsung/asynchronous). Pembelajaran daring adalah bentuk pembelajaran jarak jauh yang memanfaatkan teknologi telekomunikasi dan informasi, misalnya internet, CD-ROOM (Rudini, 2020). Tujuan penelitian ini adalah mengatahui sejauhmana peran dalam pembelajaran daring dimasa pandemi covid-19.

\section{METODE}

Jenis penelitian yang digunakan adalah penelitian kualitatif. Metode Penelitian kualitatif adalah penelitian yang digunakan untuk meneliti pada kondisi objek alamiah, dimana peneliti merupakan instrumen kunci (Sugiono, 2015). Perbedaannya dengan penelitian kuantitatif adalah penelitian ini berangkat dari data, memanfaatkan teori yang ada sebagai bahan penjelas dan berakhir dengan sebuah teori. Subyek penelitian ini adalah 27 responden wali murid kelas 3A SD Negeri 1 Panunggalan. Pada kajian ini peneliti menggunakan angket atau lembar survey melalui google form. Angket merupakan pengumpulan data yang berupa pertanyaan yang tertulis untuk responden.

Teknik analisis data mempunyai prinsip yaitu untuk mengolah data dan menganalisis data yang terkumpul menjadi data yang sistematis, teratur, terstruktur, dan mempunyai makna (Kuncahyono, 2017). Pada analisis data angket, peneliti menggunakan skala likers. Dimana skala likers merupakan skala yang bertujuan untuk mengukur sikap, pendapat suatu objek yang diteliti. Kriteria yang digunakan dalam penelitian ini yaitu menggunakan sangat setuju (SS), setuju (S), ragu-ragu ( R), tidak setuju (TS), sangat tidak setuju (STS). Angket terdiri dari 28 pertanyaan yang berisikan 14 pernyataan yang negative dan 14 pernyataan positif.

\section{HASIL}

Penelitian ini untuk melihat bagaimana peran orangtua selama proses pembelajaran di rumah (pembelajaran daring) selama pandemic covid-19. Pembelajaran di rumah dengan dibimbing orangtua juga akrab dikenal dengan nama PJJ atau pembelajaran jarak jauh, karena dilakukan di rumah masing-masing. Hasil dari penelitian ini orangtua yang merasa sangat setuju pembelajaran di rumah dapat membantu anak dalam belajar selama pandemic covid 19 sebanyak 5 responden atau $18,52 \%$, orangtua memberikan motivasi kepada anak selama pembelajaran berlangsung di rumah sebanyak 5 responden atau 18,52\%, orangtua merasa lebih mudah mengerjakan pekerjaan rumah jika anak belajar di sekolah sebanyak 9 responden atau 33,33\%, dan orangtua merasa senang kepada guru yang selalu memberikan tugas kepada anak sebanyak 10 responden atau $37,04 \%$.

Berikut ini adalah hasil angket yang telah diberikan penilaian oleh orangtua siswa yang ikut membimbing anaknya dalam melakukan pembelajaran di rumah, angket ini berisi tentang pernyataan positif pada tabel 1 berikut:

\section{Tabel 1 Hasil angket peran orangtua selama pembelajaran daring (pernyataan positif)}

\begin{tabular}{lllllll}
\hline \multirow{2}{*}{ No } & \multicolumn{1}{c}{ Pernyataan } & \multicolumn{5}{c}{ Pilihan Jawaban } \\
1 & $\begin{array}{l}\text { Pembelajaran di rumah sangat efektif untuk diterapkan. } \\
\text { Melalui pembelajaran di rumah dapat meningkatkan }\end{array}$ & 4 & 13 & 0 & 8 & 2 \\
2 & 14 & 3 & 6 & 1 \\
3 & $\begin{array}{l}\text { kualitas pembelajaran anak saya. } \\
\text { Pembelajaran di rumah lebih menguntungkan daripada }\end{array}$ & 3 & 16 & 5 & 4 & 0 \\
pembelajaran biasa. & Melalui pembelajaran di rumah dapat mempererat & 1 & 6 & 4 & 16 & 0 \\
\hline
\end{tabular}




\begin{tabular}{|c|c|c|c|c|c|c|}
\hline & engan anak sava. & & & & & \\
\hline 5 & $\begin{array}{l}\text { Melalui pembelajaran di rumah, saya dapat melihat } \\
\text { perkembangan anak saya dalam belajar. }\end{array}$ & 1 & 5 & 5 & 16 & 0 \\
\hline 6 & $\begin{array}{l}\text { Anak saya melakukan pembelajaran di rumah dengan } \\
\text { sangat baik. }\end{array}$ & 0 & 6 & 11 & 10 & 0 \\
\hline 7 & $\begin{array}{l}\text { Pembelajaran di rumah dapat membantu anak saya dalam } \\
\text { belajar selama pandemic covid- } 19 \text {. }\end{array}$ & 0 & 6 & 0 & 16 & 5 \\
\hline 8 & $\begin{array}{l}\text { Selama pembelajaran di rumah, saya selalu membantu } \\
\text { anak saya saat mengerjakan tugas. }\end{array}$ & 0 & 4 & 2 & 18 & 3 \\
\hline 9 & $\begin{array}{l}\text { Sebagai orangtua, saya memberikan motivasi kepada anak } \\
\text { saya selama berlangsungnya pembelajaran di rumah. }\end{array}$ & 0 & 0 & 1 & 21 & 5 \\
\hline 10 & Pembelajaran di sekolah memiliki sedikit pengeluaran. & 2 & 4 & 7 & 13 & 1 \\
\hline 11 & $\begin{array}{l}\text { Sebagai orangtua, pembelajaran di rumah dapat } \\
\text { meningkatkan pengetahuan Teknologi, Informasi, dan } \\
\text { Komunikasi (TIK) bagi anak saya. }\end{array}$ & 1 & 10 & 5 & 8 & 1 \\
\hline 12 & $\begin{array}{l}\text { Saya lebih mudah mengerjakan pekerjaan rumah jika anak } \\
\text { saya belajar di sekolah. }\end{array}$ & 2 & 3 & 0 & 13 & 9 \\
\hline 13 & $\begin{array}{l}\text { Tugas yang diberikan dari sekolah dalam pembelajaran di } \\
\text { rumah tidak begitu sulit, sehingga saya masih mampu } \\
\text { membantu anak saya dalam menyelesaikan tugasnya. }\end{array}$ & 1 & 8 & 2 & 14 & 2 \\
\hline 14 & $\begin{array}{l}\text { Saya merasa senang kepada guru yang selalu memberikan } \\
\text { tugas kepada anak saya. }\end{array}$ & 1 & 2 & 5 & 9 & 10 \\
\hline
\end{tabular}

Berikut ini adalah angket yang telah diberikan penilaian oleh orangtua siswa yang ikut membimbing anaknya dalam melakukan pembelajaran di rumah, angket ini berisi pernyataan negatif dapat dijabarkan pada tabel 2 sebrikut:

Tabel 2 hasil angket peran orangtua selama pembelajaran daring (pernyataan negatif)

\begin{tabular}{|c|c|c|c|c|c|c|}
\hline \multirow{2}{*}{ No } & \multirow{2}{*}{ Pernyataan } & \multicolumn{5}{|c|}{ Pilihan Jawaban } \\
\hline & & STS & TS & $\mathbf{R}$ & $\mathbf{S}$ & SS \\
\hline 1 & $\begin{array}{l}\text { Pembelajaran di sekolah tidak lebih efektif dari pembelajaran } \\
\text { di rumah. }\end{array}$ & 3 & 19 & 3 & 1 & 1 \\
\hline 2 & $\begin{array}{l}\text { Pembelajaran di sekolah kurang dapat meningkatkan kualitas } \\
\text { pembelajaran bagi anak saya. }\end{array}$ & 3 & 23 & 0 & 0 & 1 \\
\hline 3 & $\begin{array}{l}\text { Pembelajaran di sekolah tidak lebih menguntungkan anak } \\
\text { saya sebagai siswa. }\end{array}$ & 6 & 20 & 1 & 0 & 0 \\
\hline 4 & $\begin{array}{l}\text { Pembelajaran di sekolah meregangkan hubungan saya } \\
\text { dengan anak saya. }\end{array}$ & 6 & 20 & 0 & 1 & 0 \\
\hline 5 & $\begin{array}{l}\text { Dengan pembelajaran di sekolah saya tidak dapat melihat } \\
\text { langsung perkembangan anak saya dalam belajar. }\end{array}$ & 4 & 19 & 3 & 1 & 0 \\
\hline 6 & Anak saya merasa terganggu saat belajar di sekolah. & 8 & 19 & 0 & 0 & 0 \\
\hline 7 & $\begin{array}{l}\text { Pembelajaran di rumah tidak dapat membantu anak saya } \\
\text { sama sekali. }\end{array}$ & 1 & 10 & 8 & 7 & 1 \\
\hline 8 & $\begin{array}{l}\text { Saya tidak pernah membantu anak saya belajar jika } \\
\text { pembelajaran di sekolah seperti biasa. }\end{array}$ & 5 & 21 & 1 & 0 & 0 \\
\hline 9 & Saya tidak pernah memberikan motivasi selama anak saya & 5 & 22 & 0 & 0 & 0 \\
\hline
\end{tabular}




\begin{tabular}{|c|c|c|c|c|c|c|}
\hline & di sekolah seperti biasa. & & & & & \\
\hline 10 & $\begin{array}{l}\text { Sebagai orangtua, saya merasa pembelajaran di rumah } \\
\text { memiliki banyak pengeluaran. }\end{array}$ & 2 & 11 & 3 & 8 & 3 \\
\hline 11 & $\begin{array}{l}\text { Saat pembelajaran di rumah, anak saya lebih banyak } \\
\text { memegang HP disbanding mengobrol dengan saya. }\end{array}$ & 1 & 7 & 5 & 9 & 5 \\
\hline 12 & $\begin{array}{l}\text { Saya merasa kesulitan dalam membagi waktu antara } \\
\text { melakukan pekerjaan rumah dengan membantu anak saya } \\
\text { dalam belajar secara daring. }\end{array}$ & 1 & 8 & 1 & 11 & 6 \\
\hline 13 & $\begin{array}{l}\text { Tugas yang diberikan guru selama pembelajaran di rumah } \\
\text { sangat sulit sekali. }\end{array}$ & 0 & 11 & 5 & 9 & 2 \\
\hline 14 & $\begin{array}{l}\text { Saya sangat tidak menyukai guru yang memberikan tugas } \\
\text { yang banyak kepada anak saya. }\end{array}$ & 2 & 9 & 4 & 12 & 0 \\
\hline
\end{tabular}

\section{PEMBAHASAN}

Berdasarkan data yang telah dimuat pada tabel 1 dan 2, dapat diketahui bahwa orangtua dalam pembelajaran daring kurang efektif untuk diterapkan tetapi bukan berarti pembelajaran secara daring tidak efektif. Hal ini dikarenakan pembelajaran di rumah lebih cenderung kepada banyaknya pemberian tugas yang dapat dibantu atau dibimbing orangtua selama pembelajaran daring. Banyak dari orangtua memberikan motivasi selama siswa belajar daring karena himbauan pemerintah mengenai covid-19, hal ini juga yang membuat tidak sedikit orangtua meluangkan waktu untuk menemani anak belajar (F. Handayani, 2020a). Sehingga orangtua dapat mengetahui perkembangan belajar anak selama dirumah, dan dapat juga membantu anak dalam mengerjakan tugas yang diberikan guru.

Selama pembelajaran di rumah atau daring, tugas yang diberikan guru tidak sedikit dari orangtua yang merasa tugas yang diberikan guru lebih banyak. Namun, orangtua tidak menaruh rasa benci. Sebagian besar orangtua senang karena tugas mampu membantu siswa dalam mengerti dan memahami materi lebih banyak dengan latihan soal. Banyak orangtua yang menilai bahwa pembelajaran di rumah atau daring dapat mempererat hubungannya dengan anak (R. Handayani, 2020), begitupun anaknya dinilai dapat melakukan pembelajaran dirumah dengan sangat baik. Sehingga peran orangtua dalam pembelajaran daring selama pandemi covid-19 sangat berpengaruh terhadap hasil belajar siswa. Dengan peran orangtua sebagai pembimbing, motivator dan pendamping untuk anak selama pembelajaran daring.

\section{KESIMPULAN}

Dengan adanya kebijakan dari pemerintah untuk belajar dari rumah atau daring, maka peran orangtua sebagai pengganti guru sangat penting. Peran orangtua juga sangat diperlukan untuk memberikan edukasi kepada anak-anaknya yang masih belum bisa memahami tentang pandemi, agar tidak tertular maka harus berdiam diri dirumah saja.

Peran orangtua dalam pembelajaran daring selama pandemi covid-19 yaitu 1) dalam pembelajaran daring kurang efektif untuk diterapkan tetapi bukan berarti pembelajaran secara daring tidak efektif. Hal ini dikarenakan pembelajaran di rumah lebih cenderung kepada banyaknya pemberian tugas yang dapat dibantu atau dibimbing orangtua selama pembelajaran daring. 2) pembelajaran di rumah atau daring dinilai tetap mampu meningkatkan kualitas pembelajaran begitupun dengan pembelajaran di sekolah. Walaupun banyak orangtua tidak setuju jika pembelajaran daring dapat meningkatkan kualitas pembelajaran, karena orangtua tetap beranggapan bahwa kualitas pembelajaran lebih meningkat apabila diterapkan disekolah. 3) orangtua memberikan motivasi selama siswa belajar daring karena himbauan pemerintah 
mengenai covid-19, hal ini juga yang membuat tidak sedikit orangtua meluangkan waktu untuk menemani anak belajar. 4) orangtua yang menilai bahwa pembelajaran di rumah atau daring dapat mempererat hubungannya dengan anak, begitupun anaknya dinilai dapat melakukan pembelajaran dirumah dengan sangat baik. Dengan peran orangtua sebagai pembimbing, motivator dan pendamping untuk anak selama pembelajaran daring.

\section{REFERENSI}

Arrosyad, M. I., Nuriani, W., \& ... (2021). Pelatihan Pengembangan Potensi UMKM Dodol Singkong Desa Renggiang di Masa Pandemi Covid 19. JCSE: Journal of ..., 2(1), 1-8. http://journal.stieputrabangsa.ac.id/index.php/jcse/article/view/748

Divayana, D. G. H. (2017). Evaluasi Pemanfaatan E-Learning di Universitas Teknologi Indonesia Menggunakan Model CSE-UCLA. Jurnal Cakrawala Pendidikan, 36(2), 280-289. https://doi.org/10.21831/cp.v36i2.12853

Fhatri, Z. (2020). Intervensi Latihan Sensori Motorik Dalam Pengembangan Kinestetik Anak Autis. Tarbany: Jurnal Pendidikan Islam, 7(1), 23-36. https://doi.org/10.32923/tarbawy.v7i1.1184

Handayani, F. (2020a). Building Students ' Critical Thinking Skills through STEM-Based Digital Literacy during the Pandemic Period Covid 19. Cendekiawan, 2(2), 69-74.

Handayani, F. (2020b). Membangun Keterampilan Berpikir Kritis Siswa Melalui Literasi Digital Berbasis STEM pada Masa Pandemik Covid 19. Cendekiawan, 2(2), 69-72. https://doi.org/10.35438/cendekiawan.v2i2.184

Handayani, R. (2020). Multi Peran Wanita Karir Pada Masa Pandemi Covid-19. Jurnal Kajian Gender Dan Anak, 04(1), 1-10.

Jannet, H. (2015). Pendidikan Agama Dalam Kultur Sekolah Demokratis: Potensi Membumikan Deradikalisasi Agama Di Sekolah. Walisongo: Jurnal Penelitian Sosial Keagamaan, 23(1), 51. https://doi.org/10.21580/ws.2015.23.1.223

Kuncahyono, K. (2017). Analisis Penerapan Media Berbasis Komputer Pada Pembelajaran Tematik Terpadu Di Sekolah Dasar. Jurnal Pemikiran Dan Pengembangan Sekolah Dasar (JP2SD), 5(2), 773. https://doi.org/10.22219/jp2sd.vol5.no2.773-780

Lailiyah, I., \& Ridlwan, B. (2020). Peran Wanita Karir Dalam Pendidikan Islam. Al-Misbab (Jurnal Islamic Studies), 8(2), 74-78. https://doi.org/10.26555/almisbah.v8i2.1151

Lyimo, N. S., Too, J. K., \& Kipng'etich, K. J. (2017). Perception of teachers on availability of instructional materials and physical facilities in secondary schools of Arusha District, Tanzania. International Journal of Educational Policy Research and Review, 4(5), 103-112.

Prasetyo, H., \& Sutopo, W. (2018). Industri 4.0: Telaah Klasifikasi Aspek Dan Arah Perkembangan Riset. Jati Undip: Jurnal Teknik Industri, 13(1), 17. https://doi.org/10.14710/jati.13.1.17-26

Prastyo, E., \& Nuswantari, S. (2020). Learning Thematic Covid-19 With SETS Vision Integrated Local Wisdom For Elementary School. Cendekiawan, 2(1), 20-27. https://doi.org/10.35438/cendekiawan.v2i1.173 
Rifqi, H. (2016). Analisis Semiotika Logo Bank Nagari Bank Pembangunan Daerah Sumatera Barat. Journal of Chemical Information and Modeling, 53(9), 1689-1699.

Risthantri, P., \& Sudrajat, A. (2015). Relationship Between Parenting Parents and Obedience to Worship With Students' Polite Behavior Relationship Between Parenting Parents and Worship Obedience With Good Manners for Junior High School Students. Social Harmony: Jurnal Pendidikan IPS, 2(2), 191-202.

Rudini, R. (2020). Aktualisasi Nilai-Nilai Islam Dalam Pembentukan Karakter Mahasiswa Di Pondok Pesantren Nurul Ummah Kotagede Yogyakarta. Tarbawy : Jurnal Pendidikan Islam, 7(1), 47-60. https://doi.org/10.32923/tarbawy.v7i1.1185

Siregar, F. R. (2018). Nilai-Nilai Budaya Sekolah dalam Pembinaan Aktivitas Keagamaan Siswa SD IT Bunayya Padangsidimpuan. Jurnal Kajian Gender Dan Anak, 1(1), 129-139. https://doi.org/10.24952/gender.v1i1.777

Sugiono. (2015). Analisis Penyediaan dan Penggunaan Modal Kerja UMKM (Usaha Mikro, Kecil dan Menengah) dalam Meningkatkan Laba Usaha pada KUB (Kelompok Usaha Besama) Alam Lestari Depok. Prosiding Semiar Nasional Pendidikan Ekonomi \& Bisnis.

Surur, A. M. (2018). Upaya Menanamkan Nilai Religius Siswa Di Man Kediri 1 Kota Kediri Dengan Ekstrakurikuler Keagaman Tahfidz Al-Qur'an. Jurnal Pendidikan Agama Islam, 15(1), 42-51. https://doi.org/10.14421/jpai.2018.151-03

Suspahariati, \& Susilawati, R. (2020). Penerapan Sistem WFH (Work From Home) dan Dampaknya terhadap Kinerja Staf dan Dosen Unipdu Jombang selama Pandemi Covid-19. Jurnal Manajemen Dan Pendidikan Islam, 6(2), 229-240. 